\title{
A randomized, open-label study comparing low-dose clevudine plus adefovir combination therapy with clevudine monotherapy in naïve chronic hepatitis $B$ patients
}

\author{
Won Young Tak $\cdot$ Jin Mo Yang $\cdot$ Byung Ik Kim • \\ Soon Koo Baik · Gab Jin Cheon · Kwan Soo Byun • \\ Do Young Kim • Byung Chul Yoo
}

Received: 11 November 2013 / Accepted: 21 April 2014/Published online: 25 May 2014

(C) The Author(s) 2014. This article is published with open access at Springerlink.com

\begin{abstract}
Purpose Clevudine $30 \mathrm{mg}$ showed potent antiviral activity with a marked post-treatment antiviral effect. However, long-term treatment with clevudine monotherapy induced resistance and myopathy in some cases. The objective of this study is to evaluate the preliminary efficacy and safety of the combination of clevudine $20 \mathrm{mg}$ and adefovir compared to clevudine monotherapy.

Methods Seventy-four patients were randomized to either a combination of clevudine $20 \mathrm{mg}$ and adefovir or clevudine 20 or $30 \mathrm{mg}$ and were treated for 2 years. The viral kinetics for 24 weeks, virological response [VR; hepatitis B virus (HBV) DNA less than 300 copies/ml], and the biochemical response [BR; normal alanine aminotransferase (ALT)] were assessed.
\end{abstract}

\section{W. Y. Tak}

Department of Internal Medicine, Kyungpook National

University Hospital, Daegu, Republic of Korea

e-mail: wytak@knu.ac.kr

\section{J. M. Yang}

Department of Internal Medicine, The Catholic University

Medical College St. Vincent's Hospital, Suwon,

Republic of Korea

e-mail: jmyangdr@catholic.ac.kr

\section{B. I. Kim}

Division of Gastroenterology and Hepatology, Kangbook Samsung Hospital, Sungkyunkwan University School of

Medicine, Seoul, Republic of Korea

e-mail: bik.kim@samsung.com

\section{S. K. Baik}

Department of Internal Medicine, Yonsei University Wonju College of Medicine, Wonju, Republic of Korea

e-mail: baiksk@yonsei.ac.kr
Results There was no difference in baseline characteristics among the three groups. Viral kinetics study showed no statistically significant difference among them during 24 weeks. The combination group showed $95 \%$ virological response with a statistically significant difference compared to the clevudine $30 \mathrm{mg}(67 \%)$ and $20 \mathrm{mg}$ $(71 \%)$ groups $(p=0.0376)$. Biochemical response rates were similar in all groups (78-94\%). No resistance was reported in the combination group, while $20 \%$ of patients treated with clevudine $30 \mathrm{mg}$ or $20 \mathrm{mg}$ reported resistance during 2 years. Muscle-related symptoms such as myalgia ( 1 in clevudine $30 \mathrm{mg}, 1$ in the combination group) and muscle weakness ( 1 in clevudine $30 \mathrm{mg}, 2$ in clevudine $20 \mathrm{mg}$ ) were reported in five patients $(7 \%)$; of these, three patients discontinued the study.

\section{G. J. Cheon}

Department of Internal Medicine, GangNeung Asan Hospital, University of Ulsan College of Medicine, Gangneung,

Republic of Korea

e-mail: 1000@gnah.co.kr

\section{K. S. Byun}

Department of Internal Medicine, Korea University Guro

Hospital, Seoul, Republic of Korea

e-mail: kwsbyun@unitel.co.kr

\section{Y. Kim}

Department of Internal Medicine, Yonsei University College of Medicine, Seoul, Republic of Korea

e-mail: DYK1025@yuhs.ac

\section{B. C. Yoo $(\bowtie)$}

Department of Internal Medicine, Samsung Medical Center, Sungkyunkwan University School of Medicine, Seoul,

Republic of Korea

e-mail: bc11.yoo@samsung.com 
Conclusion We concluded that the combination of clevudine $20 \mathrm{mg}$ and adefovir produced a potent antiviral response together with a good resistance profile compared to clevudine monotherapy at 96 weeks in this pilot study.

Keywords Adefovir - Clevudine - Combination therapy · Hepatitis B virus · Resistance · Viral kinetics

\section{Introduction}

Although effective vaccines are available in many countries, hepatitis B virus (HBV) infection still constitutes a global health threat since it can develop into liver cirrhosis and hepatocellular carcinoma [1-3].

There are several oral antiviral agents, including lamivudine, adefovir, telbivudine, entecavir, and tenofovir, available worldwide, and clevudine in Korea the and Philippines, for the treatment of $\mathrm{HBV}$ infection. These drugs were used as monotherapy in their clinical trials. However, drug-induced mutations often emerged during monotherapy with nucleos(t)ides, which were associated with viral breakthrough and clinical deterioration [4]. Recently, the combination of nucleos(t)ides has been recommended to avoid such mutations [5] despite its nonsynergic effect [6].

Clevudine [7] showed very potent antiviral activity with the unique advantage of sustained viral suppression after withdrawal of treatment, which was demonstrated in several clinical studies [8-10]. However, long-term therapy showed the development of drug resistance [ $(0.7,7.6 \%)$ for 1 year] $[11,12]$ and skeletal myopathy $[(1.7,3.9 \%)$ for 96 weeks] [12-15]. The clevudine-related mutation was rtM204I, as reported in previous publications [16]. Adefovir dipivoxil, which is an acyclic phosphonate, is not a highly potent drug against wild-type hepatitis B virus, but relatively potent against mutations with rtM204I [17-19].

In this study, we predicted that combination treatment with clevudine and adefovir may have additive or synergistic antiviral activity in patients with chronic hepatitis B because adefovir acts as a chain terminator and reduces the emergence of resistance.

Global studies on clevudine were voluntarily suspended in the USA by the sponsor because of the myopathy reported in Korea; clevudine had only been approved in Korea at that time. However, the Korean FDA scrutinized all of the safety data including muscle-related symptoms and then decided that clevudine could be marketed because its associated myopathy is not life threatening and is reversible when the patient is taken off the drug. Based on the results of Emax modeling using AAUCMB (HBV DNA average area under the curve minus baseline), the maximal predicted treatment efficacy of clevudine was 77,91 , and
$94 \%$ with doses of 10,30 , and $50 \mathrm{mg}$, QD, respectively [8].

We speculate that the reduced amount of clevudine at $20 \mathrm{mg}$ can produce almost the same antiviral activity as clevudine $30 \mathrm{mg}$ based on Emax modeling and may reduce the incidence of myopathy.

This study was designed to evaluate the preliminary antiviral activity and safety of the combination of clevudine $20 \mathrm{mg}$ and adefovir versus monotherapy of clevudine $30 \mathrm{mg}$ and $20 \mathrm{mg}$.

\section{Materials and methods}

Study design

This was a prospective, randomized, open-label trial to evaluate the preliminary efficacy and safety of the combination of clevudine $20 \mathrm{mg}$ and adefovir compared to clevudine monotherapy in chronic hepatitis B patients enrolled at eight clinical centers in South Korea. All patients were randomly assigned to be treated with either clevudine $30 \mathrm{mg}, 20 \mathrm{mg}$, or a combination of clevudine $20 \mathrm{mg}$ and adefovir in a 1:1:1 ratio. The randomization list was produced using SAS before the study. Randomization was done with stratification on the basis of the study site, in blocks of three or six.

Patients were monitored at baseline, days 4, 7, 10, 14, weeks 3, 4, 8, 12, 24, 36, 48, 60, 72, 84, and 96 during the study period. Patients underwent physical examinations and blood samplings to measure laboratory parameters and HBV DNA levels according to the protocol. A viral kinetics study during the 24-week treatment period was also performed for all the enrolled patients.

The study was conducted in compliance with the principles of the Declaration of Helsinki and in accordance with Good Clinical Practice guidelines. Written informed consent, which was approved by the Institutional Review Board, was obtained from all of the subjects before they were examined for eligibility criteria. This study is registered as NIH clinical trial NCT01264354.

Study population

Eligible patients were 18 years and older and had been hepatitis B surface antigen positive for at least 6 months. Patients had HBV DNA levels higher than $1 \times 10^{5}$ copies $/ \mathrm{ml}$ and abnormal ALT levels. Patients were asked to give written informed consent prior to study start and to comply with the study requirements. Patents who had been receiving interferon or peg-interferon within 6 months before enrollment were excluded. Patients previously treated with clevudine, lamivudine, adefovir, entecavir, 
telbivudine, tenofovir, or any other investigational drug for HBV infection were also excluded. The exclusion criteria included currently receiving antiviral, immunomodulatory, cytotoxic, or corticosteroid therapy; clinical evidence of decompensated liver disease such as total bilirubin $\geq 2.0 \mathrm{mg} / \mathrm{dl}$; prothrombin time $\geq 1.7$ (INR); albumin $<3.5 \mathrm{~g} / \mathrm{dl}$; co-infection with hepatitis C, D, or the human immunodeficiency virus; evidence of ascites, variceal hemorrhage, or hepatic encephalopathy or hepatocellular carcinoma; history of liver transplantation. Patients who were pregnant or breast-feeding were also excluded.

\section{Efficacy endpoints}

The primary endpoint was the proportion of patients with HBV DNA less than 300 copies/ml by real-time PCR at week 24. HBV DNA levels were measured at a central laboratory using the COBAS AmpliPrep/COBAS TaqMan HBV Test, v2.0 (Roche, Branchburg, NJ, USA), with a detection limit of 116 copies/ml.

Secondary endpoints included the reduction in $\mathrm{HBV}$ DNA, as defined as a mean $\log _{10}$ decrease from baseline, the proportion of patients with normal ALT, hepatitis B envelop antigen (HBeAg) loss, and/or seroconversion. The viral breakthrough was defined as a $1 \log _{10}$ increase from nadir during the treatment period. RFMP analysis (Invitrogen, Carlsbad, CA, USA) on rtM204 and rtM180 sites was performed on the patients who showed viral breakthrough.

\section{Viral kinetics over the first 24 weeks}

Serial HBV DNA samples were analyzed by a viral load function previously applied to the clearance kinetics of HBV from serum during a lamivudine and clevudine viral dynamics study [20]. The efficacy $(\varepsilon)$ of inhibition of viral production, free virus clearance rate constant $(\mu)$, and infected cell loss rate constant $(a)$ were determined by fitting the viral load function to the data using non-linear regression.

$V(t)=V_{0} e^{-\mu t}+\frac{(1-\varepsilon) \mu V_{0}\left(e^{-a t}-e^{-\mu t}\right)}{\mu-a}$

Safety analysis

Safety analysis included data from all 73 eligible patients who received at least one dose of study medication after randomization. Adverse events (AE), serious adverse events (SAE), and laboratory toxicity were included in the safety evaluations. If toxicities were not presented at baseline but appeared during the trial, or worsened in severity from baseline, laboratory toxicities were recorded. Muscle-related symptoms, including myopathy, were evaluated according to the guideline attached to the protocol.
Statistical analysis

The results were analyzed on an intention-to-treat basis for the efficacy analysis. Patients discontinuing the study after receiving the first study drug dose were included in the efficacy analysis until their discontinuation. The patients who received at least one of the study medications after randomization were included in the safety analysis.

Statistical analysis was performed using SAS version 9.2 (SAS Institute, Cary, NC, USA). Determination of statistical significance was performed with an alpha level of 0.05. Comparisons of categorical variables were performed by chi-square test or Fisher's exact test, and continuous variables were analyzed by one-way ANOVA test or Kruskal-Wallis test.

\section{Results}

Study population

A total of 73 eligible patients were enrolled at 8 sites and randomly assigned to receive the clevudine $30 \mathrm{mg}$ daily $(n=25)$, clevudine $20 \mathrm{mg}$ daily $(n=24)$, or the combination (clevudine $20 \mathrm{mg}$ and adefovir) daily $(n=24)$. Baseline characteristics including the HBV DNA level and ALT levels were similar among the three groups (Table 1). At baseline, $\mathrm{HBeAg}$-positive patients were $72 \%(N=18)$, $63 \%(N=15)$, and $63 \%(N=15)$ in the clevudine $30 \mathrm{mg}, 20 \mathrm{mg}$, and combination group, respectively.

A total of 16 patients withdrew from the study. Hence, 57 patients (18 in the clevudine $30 \mathrm{mg}$ group, 17 in the clevudine $20 \mathrm{mg}$ group, and 22 in the combination group) completed the 96-week treatment period. Seven patients discontinued the study in the clevudine $30 \mathrm{mg}$ group because of resistance (4), adverse events (2), and loss to follow-up (1); 7 patients in the clevudine $20 \mathrm{mg}$ group because of resistance (3), withdrawal of consent (2), adverse events (1), and loss to follow-up (1); 2 patients in the combination group because of withdrawal of consent (2). For the viral kinetics analysis, 24, 23, and 20 patients were included in the clevudine $30 \mathrm{mg}, 20 \mathrm{mg}$, and combination groups, respectively.

Virologic and serologic endpoints

The proportions of patients with HBV DNA levels less than 300 copies/ml by real-time PCR assay at 24 weeks, which was a primary efficacy endpoint, were 60,59 , and $57 \%$ in the clevudine $30 \mathrm{mg}, 20 \mathrm{mg}$, and combination groups, respectively, without a statistically significant difference ( $p=0.9688$ ) (Table 2). The proportions of patients with HBV DNA levels less than 300 copies/ml at week 96 were 
Table 1 Baseline characteristics

\begin{tabular}{lllll}
\hline Characteristics & CLV 30 mg $(n=25)$ & CLV 20 mg $(n=24)$ & CLV 20 mg + ADV 10 mg $(n=24)$ & $p$ value \\
\hline Male (\%) & 52.00 & 62.50 & 50.00 & $0.6451^{\text {a }}$ \\
Age (year) & $44.16 \pm 10.14$ & $45.08 \pm 12.83$ & $48.92 \pm 11.73$ & $0.3233^{\text {b }}$ \\
Weight (kg) & $64.66 \pm 12.00$ & $64.07 \pm 11.05$ & $64.65 \pm 12.71$ & $0.9806^{\text {b }}$ \\
HBV DNA (log copies/ml) ${ }^{\text {d }}$ & $7.21 \pm 1.41$ & $7.47 \pm 1.04$ & $7.31 \pm 1.45$ & $0.5257^{\text {c }}$ \\
ALT (U/l) & $73.96 \pm 62.02$ & $132.63 \pm 145.13$ & $125.79 \pm 162.46$ & $0.2437^{\text {c }}$ \\
HBsAg (log IU/ml) & $3.53 \pm 0.78$ & $3.66 \pm 0.68$ & $3.64 \pm 0.68$ & $0.8302^{\text {b }}$ \\
HBeAg positive (\%) & 72.00 & 62.50 & 62.50 & $0.7193^{\text {a }}$ \\
LC $(\%)$ & 32.00 & 25.00 & 20.83 & $0.6661^{\text {a }}$ \\
\hline
\end{tabular}

Data are expressed as mean \pm SD (standard deviation)

${ }^{a}$ Chi-squre test

b ANOVA test

c Kruskal-Wallis test

d 013-R007 (CLV $20 \mathrm{mg}$ ) was excluded because of missing data

e 57 patients (CLV $30 \mathrm{mg}$ : 18, CLV $20 \mathrm{mg}$ : 17, CLV $20 \mathrm{mg}+$ ADV $10 \mathrm{mg}$ : 22) who completed the week 96 visit

Table 2 Comparison of the virologic and biochemical response rates

\begin{tabular}{cclll}
\hline & CLV 30 mg & CLV 20 mg & CLV 20 mg + ADV 10 mg & $p$ value \\
\hline \multicolumn{2}{l}{ Virologic response (<300 copies/ml) } & & & \\
Week 24 & $60.00 \%(15 / 25)$ & $59.09 \%(13 / 22)$ & $56.52 \%(13 / 23)$ & $0.9688^{\mathrm{a}}$ \\
Week 48 & $66.67 \%(16 / 24)$ & $70.00 \%(14 / 20)$ & $73.91 \%(17 / 23)$ & $0.8629^{\mathrm{a}}$ \\
Week 72 & $63.64 \%(14 / 22)$ & $66.67 \%(12 / 18)$ & $81.82 \%(18 / 22)$ & $0.3692^{\mathrm{a}}$ \\
Week 96 & $66.67 \%(12 / 18)$ & $70.59 \%(12 / 17)$ & $95.45 \%(21 / 22)$ & $0.0376^{\mathrm{b}}$ \\
Biochemical response (normal ALT) & & & \\
Week 24 & $76.00 \%(19 / 25)$ & $81.82 \%(18 / 22)$ & $69.57 \%(16 / 23)$ & $0.6313^{\mathrm{a}}$ \\
Week 48 & $91.67 \%(22 / 24)$ & $85.00 \%(17 / 20)$ & $82.61 \%(19 / 23)$ & $0.6695^{\mathrm{b}}$ \\
Week 72 & $81.82 \%(18 / 22)$ & $88.89 \%(16 / 18)$ & $81.82 \%(18 / 22)$ & $0.8290^{\mathrm{b}}$ \\
Week 96 & $77.78 \%(14 / 18)$ & $94.12 \%(16 / 17)$ & $86.36 \%(19 / 22)$ & $0.4053^{\mathrm{b}}$ \\
\hline
\end{tabular}

67, 71, and $95 \%$ in the clevudine $30 \mathrm{mg}, 20 \mathrm{mg}$, and combination groups, respectively, which showed statistically significant differences $(p=0.0376)$.

The mean HBV DNA changes from baseline at week 96 were $-4.32 \pm 1.63,-4.86 \pm 1.24$, and $-5.26 \pm 1.42$ $\log _{10}$ copies/ml in the clevudine $30 \mathrm{mg}, 20 \mathrm{mg}$, and combination groups, respectively, which did not show statistically significant differences $(p<0.3534)$ (Fig. 1). At week 96 , the rates of $\mathrm{HBeAg}$ loss $(21 \%$ in the clevudine $30 \mathrm{mg}$, $40 \%$ in the clevudine $20 \mathrm{mg}$, and $21 \%$ in the combination group) and/or HBeAg seroconversion (7\% in the clevudine $30 \mathrm{mg}, 40 \%$ in the clevudine $20 \mathrm{mg}$, and $21 \%$ in the combination group) were comparable among the three groups $(p=0.5809,0.1684)$. Viral breakthroughs were observed in $28 \%$ of the clevudine $30 \mathrm{mg}, 17 \%$ of the clevudine $20 \mathrm{mg}$, and $0 \%$ of the combination group, which was significantly different $(p=0.0149)$. Among them, six patients in the clevudine $30 \mathrm{mg}$ and five patients in the clevudine $20 \mathrm{mg}$ group showed genotypic mutation

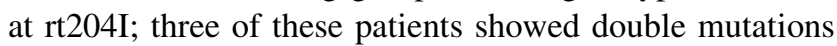

at rtM204I and rtL180M. In conclusion, clevudine-related mutation was reported in $20 \%$ of the clevudine monotherapy group, while no viral breakthrough was observed in the combination group.

Viral kinetics over the first 24 weeks

Viral dynamics over the first 24 weeks were analyzed for 67 subjects who completed treatment at 24 weeks. Table 3 summarizes the estimated parameters by treatment group. The $p$ values of the Kruskal-Wallis test were $0.934,0.489$, and 0.173 for $\varepsilon, \mu$, and $\alpha$, respectively, which did not show statistically significant differences in the median estimates among the three groups.

\section{Biochemical endpoints}

The proportions of patients who had normal ALT at week 96 were 78,94 , and $86 \%$ in the clevudine $30 \mathrm{mg}, 20 \mathrm{mg}$, 
Fig. 1 Mean changes from baseline in HBV DNA. Mean HBV DNA changes from baseline at week 96 were -4.32 , -4.86 , and $-5.26 \log _{10}$ copies $/ \mathrm{ml}$ in the clevudine $30 \mathrm{mg}$, clevudine $20 \mathrm{mg}$, and combination groups, respectively, which did not show a statistically significant difference $(p<0.3534)$

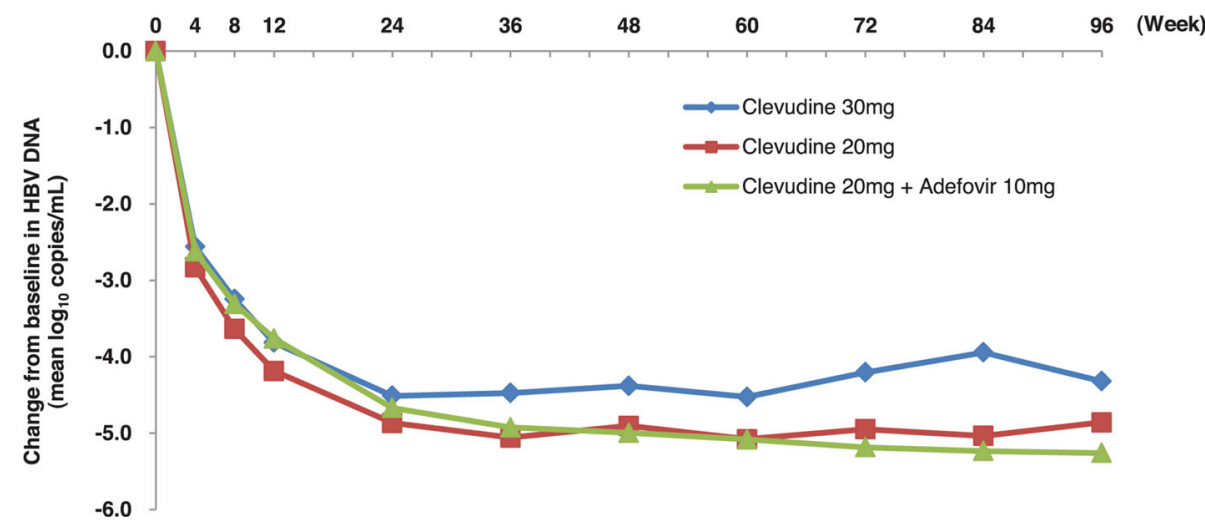

Table 3 Viral dynamic over 24 weeks

\begin{tabular}{|c|c|c|c|c|c|c|c|c|c|}
\hline Parameter & Group & $N^{\mathrm{b}}$ & N Miss ${ }^{\mathrm{c}}$ & Mean & $\mathrm{SD}$ & Median & Min. & Max. & $\overline{p \text { value }^{\mathrm{a}}}$ \\
\hline \multirow[t]{3}{*}{$\varepsilon$} & CLV $30 \mathrm{mg}$ & 24 & 1 & 0.877 & 0.201 & 0.959 & 0.120 & 1.000 & \multirow[t]{3}{*}{0.934} \\
\hline & CLV $20 \mathrm{mg}$ & 23 & 0 & 0.927 & 0.085 & 0.957 & 0.653 & 0.994 & \\
\hline & $\mathrm{CLV}+\mathrm{ADV}$ & 20 & 3 & 0.911 & 0.095 & 0.959 & 0.703 & 1.000 & \\
\hline \multirow[t]{3}{*}{$\mu$} & CLV $30 \mathrm{mg}$ & 24 & 1 & 1.672 & 2.000 & 0.761 & 0.150 & 6.331 & \multirow[t]{3}{*}{0.489} \\
\hline & CLV $20 \mathrm{mg}$ & 23 & 0 & 2.026 & 2.199 & 1.063 & 0.304 & 6.419 & \\
\hline & $\mathrm{CLV}+\mathrm{ADV}$ & 20 & 3 & 1.817 & 1.927 & 0.826 & 0.261 & 6.083 & \\
\hline \multirow[t]{3}{*}{$\alpha$} & CLV $30 \mathrm{mg}$ & 24 & 1 & 0.139 & 0.123 & 0.121 & 0.003 & 0.495 & \multirow[t]{3}{*}{0.173} \\
\hline & CLV $20 \mathrm{mg}$ & 23 & 0 & 0.166 & 0.083 & 0.130 & 0.056 & 0.337 & \\
\hline & $\mathrm{CLV}+\mathrm{ADV}$ & 20 & 3 & 0.127 & 0.099 & 0.078 & 0.003 & 0.320 & \\
\hline
\end{tabular}

${ }^{\text {a }}$ Kruskal-Wallis test

b Patients (CLV 30 mg: 013-R010, CLV 20 mg + ADV 10 mg: 013-R006, 062-R004, 062-R008) were excluded because of numerical issues (estimates were biased)

c Patients (CLV 20 mg: 013-R007, CLV 20 mg + ADV 10 mg: 022-R001) were excluded because of dropping out before 24 weeks

and combination groups, respectively $(p<0.4053)$ (Table 2).

\section{Safety and tolerability}

During the 96-week treatment period, the incidences of adverse events were similar among the three groups: 68 , 63 , and $58 \%$ in the clevudine $30 \mathrm{mg}, 20 \mathrm{mg}$, and combination groups, respectively $(p<0.7808)$. The most frequent adverse events, occurring in more than $10 \%$ of patients, were hypertension $(20 \%)$ and CPK elevation $(12 \%)$ in the clevudine $30 \mathrm{mg}$ group and upper respiratory tract infection $(17 \%)$ and CPK elevation $(13 \%)$ in the clevudine $20 \mathrm{mg}$ group. No event occurred in more than $10 \%$ of patients in the combination group. The incidence of serious adverse events during treatment was $12 \%$ ( 3 patients) only in the clevudine $30 \mathrm{mg}$ group. The SAEs of angina pectoris, arrhythmia, and inguinal hernia reported by three patients were mild or moderate in severity and considered to be unrelated to the study drugs.

Muscle-related symptoms such as myalgia and muscle weakness were reported in two patients ( 1 of myalgia, 1 of muscle weakness) in the clevudine $30 \mathrm{mg}$ group, two patients (muscle weakness) in the clevudine $20 \mathrm{mg}$ group, and one patient (myalgia) in the combination group.

Laboratory toxicities at grade 3 or higher were reported in eight patients, three patients, and four patients in the clevudine $30 \mathrm{mg}, 20 \mathrm{mg}$, and combination groups, respectively, and the difference was not statistically significant $(p=0.2738)$.

The CPK levels at grade 3 or higher were reported in 4,1 , and 3 patients in the clevudine $30 \mathrm{mg}, 20 \mathrm{mg}$, and combination groups, respectively, during the study. Two patients out of eight with CPK elevation of more than grade 3 showed muscle-related symptoms in the clevudine $30 \mathrm{mg}$ group and discontinued clevudine therapy. The other six patients continued therapy, and their CPK levels stabilized.

\section{Discussion}

The baseline characteristics of the three groups were well balanced in this randomized study. 
Based on the viral dynamics study over 24 weeks of treatment, it was speculated that the antiviral activity of the combination of clevudine $20 \mathrm{mg}$ and adefovir $10 \mathrm{mg}$ was as good as that of clevudine $30 \mathrm{mg}$.

Clevudine is known to have highly potent antiviral activity. However, the emergence of resistance during therapy is a limitation to long-term treatment. The combination of clevudine $20 \mathrm{mg}$ and adefovir also provided very potent antiviral activity, although the dose of clevudine was reduced from 30 to $20 \mathrm{mg}$.

The proportion of patients with HBV DNA less than 300 copies/ml by real-time PCR at week 96 was higher in the combination group (95\%) compared to the clevudine monotherapy groups $(67,71 \%)(p<0.0376)$, which resulted from the viral breakthrough led by the emergence of resistance in the clevudine monotherapy groups. Although direct head-to-head comparisons are not available, the antiviral activity of the combination was similar to that of tenofovir $(76 \% \mathrm{HBeAg}$-positive and $93 \% \mathrm{HBeAg}$ negative patients with HBV DNA less than 400 copies $/ \mathrm{ml}$ at week 48) [21]. We also evaluated the proportion of patients with HBV DNA less than 116 copies/ml by realtime PCR: $86 \%$ in the combination of clevudine $20 \mathrm{mg}$ and adefovir group. This result demonstrated remarkable viral suppression activity by the combination therapy. For the patients with liver cirrhosis at baseline, the proportions of patients with HBV DNA levels less than 300 copies $/ \mathrm{ml}$ did not show statistically significant differences among the three groups at week 96 ( $p=1.000$, data not shown).

In this study, it was demonstrated that combination therapy with clevudine $20 \mathrm{mg}$ and adefovir did not induce resistance, while $20 \%$ of resistance was reported in the clevudine monotherapy groups. Clevudine is a nucleoside analog and shows cross resistance to lamivudine and telbivudine, which belong to the same group of nucleoside analogs. In contrast, adefovir is a nucleotide analog. Therefore, we can speculate that combination therapy with different structures would have an advantage over monotherapy on emergence of resistance.

The biochemical response, which was defined as the proportion of normal ALT at week 96, was similar among the three groups $(p=0.4053)$. We had a limitation in the evaluation of serological response because $28-38 \%$ of $\mathrm{HBeAg}$-negative patients were included in each group, including a small number of patients.

Also, we investigated the hepatitis B surface antigen (HBsAg) reduction in 57 patients who completed the week 96 visit. The mean declines of HBsAg level from baseline were $-0.03 \pm 0.53,-0.18 \pm 0.32$, and $-0.25 \pm 0.47 \log \mathrm{IU} / \mathrm{ml}$ in the clevudine $30 \mathrm{mg}, 20 \mathrm{mg}$, and combination groups, respectively. In our study, HBsAg reduction was not obvious, although HBsAg reduction by clevudine has been published in previous papers $[22,23]$. In consideration of the low level of baseline HBsAg (3.53-3.66 log IU/ml) in this study, we can presume that HBsAg reduction by clevudine is more predominant in patients with high baseline $\mathrm{HBsAg}$ levels.

Adefovir dipivoxil is known to develop nephrotoxicity with serum creatinine elevation during administration [24]. Therefore, we investigated the change in serum creatinine in the combination groups, which did not show a statistically significant difference at week 96 from baseline (data not shown). No patients showed symptoms of nephrotoxicity during the treatment period.

During the 2-year treatment period, muscle weakness was reported in three patients treated with clevudine only. Two patients with muscle weakness in the clevudine $20 \mathrm{mg}$ group continued with the study, and the symptom disappeared during clevudine treatment. One patient with muscle weakness in the clevudine $30 \mathrm{mg}$ group discontinued with the study. The symptom of this patient was resolved after stopping clevudine treatment. Two patients with myalgia reported ( 1 in the clevudine $30 \mathrm{mg}$ and 1 in the combination group) continued with the study, and their symptoms were resolved during the study.

We planned to investigate whether the dose reduction of clevudine from 30 to $20 \mathrm{mg}$ would affect the incident rate of myopathy by clevudine. Considering these data, it is hard to conclude that the dose of clevudine is connected to musclerelated symptoms. In our study, there was no relationship between muscle weakness and CPK elevation, while it seemed that muscle weakness was followed by CPK elevation.

Due to the limitation of the sample size, a large-scale clinical study is required for the evaluation of the relationship between muscle-related symptoms and the dose, as well as the efficacy of combination therapy.

Acknowledgements This study was funded by Bukwang Pharmaceutical Co., Ltd.

Compliance with ethical requirements and Conflict of interest All procedures were conducted in compliance with the principles of the Declaration of Helsinki and in accordance with Good Clinical Practice guidelines. Written informed consent was obtained from all subjects for being included the study. Won Young Tak, Jin Mo Yang, Byung Ik Kim, Soon Koo Baik, Gab Jin Cheon, Kwan Soo Byun, Do Young Kim, Byung Chul Yoo, who took part in this study declare that they have nothing to disclose regarding funding or conflicts of interest with respect to this manuscript.

Open Access This article is distributed under the terms of the Creative Commons Attribution License which permits any use, distribution, and reproduction in any medium, provided the original author(s) and the source are credited.

\section{References}

1. Zuckerman AJ. The association of hepatitis B with primary hepatocellular carcinoma. J Infect 1983;7(Suppl 1):73-77

2. Szmuness W. Hepatocellular carcinoma and the hepatitis B virus: evidence for a causal association. Prog Med Virol 1978;24:40-69 
3. Beasley RP, Hwang LY, Lin CC, Chien CS. Hepatocellular carcinoma and hepatitis B virus. A prospective study of 22707 men in Taiwan. Lancet 1981;2(8256):1129-1133

4. Fung SK, Lok A. Management of hepatitis B patients with antiviral resistance. Antivir Ther 2004;9(6):1013-1026

5. Shakado S, Watanabe H, Tanaka T, Morihara D, Nishizawa S, Inomata $\mathrm{S}$, Ueda $\mathrm{S}$, et al. Combination therapy of lamivudine and adefovir in Japanese patients with chronic hepatitis B. Hepatol Int 2008;2(3):361-369

6. Peters MG, Hann Hw H, Martin P, Heathcote EJ, Buggisch P, Rubin R, Bourliere $\mathrm{M}$, et al. Adefovir dipivoxil alone or in combination with lamivudine in patients with lamivudine-resistant chronic hepatitis B. Gastroenterology 2004;126(1):91-101

7. Chu CK, Ma T, Shanmuganathan K, Wang C, Xiang Y, Pai SB, Yao GQ, et al. Use of 2'-fluoro-5-methyl-beta-L-arabinofuranosyluracil as a novel antiviral agent for hepatitis B virus and Epstein-Barr virus. Antimicrob Agents Chemother 1995;39(4): 979-981

8. Marcellin P, Mommeja-Marin H, Sacks SL, Lau GK, Sereni D, Bronowicki JP, Conway B, et al. A phase II dose-escalating trial of clevudine in patients with chronic hepatitis B. Hepatology 2004;40(1):140-148

9. Lee HS, Chung YH, Lee K, Byun KS, Paik SW, Han JY, Yoo K, et al. A 12-week clevudine therapy showed potent and durable antiviral activity in $\mathrm{HBeAg}$-positive chronic hepatitis B. Hepatology 2006;43(5):982-988

10. Yoo BC, Kim JH, Kim TH, Koh KC, Um SH, Kim YS, Lee KS, et al. Clevudine is highly efficacious in hepatitis B e antigennegative chronic hepatitis $\mathrm{B}$ with durable off-therapy viral suppression. Hepatology 2007;46(4):1041-1048

11. Lee JS, Park ET, Kang SS, Gu ES, Kim JS, Jang DS, Lee KS, et al. Clevudine demonstrates potent antiviral activity in naive chronic hepatitis B patients. Intervirology 2010;53(2):83-86

12. Kim SB, Song IH, Kim YM, Noh R, Kang HY, Lee Hle, Yang $\mathrm{HY}$, et al. Long-term treatment outcomes of clevudine in antiviral-naive patients with chronic hepatitis B. World J Gastroenterol 2012;18(47):6943

13. Seok JI, Lee DK, Lee CH, Park MS, Kim SY, Kim HS, Jo HY, et al. Long-term therapy with clevudine for chronic hepatitis B can be associated with myopathy characterized by depletion of mitochondrial DNA. Hepatology 2009;49(6):2080-2086

14. Tak WY, Park SY, Jung MK, Jeon SW, Cho CM, Kweon YO, Kim SK, et al. Mitochondrial myopathy caused by clevudine therapy in chronic hepatitis B patients. Hepatol Res 2009;39(9):944-947

15. Jang JH, Kim JW, Jeong SH, Myung HJ, Kim HS, Park YS, Lee $\mathrm{SH}$, et al. Clevudine for chronic hepatitis B: antiviral response, predictors of response, and development of myopathy. J Viral Hepat 2011;18(2):84-90

16. Kwon SY, Park YK, Ahn SH, Cho ES, Choe WH, Lee CH, Kim $\mathrm{BK}$, et al. Identification and characterization of clevudine-resistant mutants of hepatitis B virus isolated from chronic hepatitis B patients. J Virol 2010;84(9):4494-4503

17. De Clercq E, Holy A, Rosenberg I, Sakuma T, Balzarini J, Maudgal PC. A novel selective broad-spectrum anti-DNA virus agent. Nature 1986;323(6087):464-467

18. Sherman M. Personal view: the management of chronic hepatitis B infection. Aliment Pharmacol Ther 2006;23(7):857-869

19. Suzuki F, Kumada H, Nakamura H. Changes in viral loads of lamivudine-resistant mutants and evolution of HBV sequences during adefovir dipivoxil therapy. J Med Virol 2006;78(8): 1025-1034

20. Lau GK, Leung N. Forty-eight weeks treatment with clevudine $30 \mathrm{mg}$ qd versus lamivudine $100 \mathrm{mg}$ qd for chronic hepatitis B infection: a double-blind randomized study. Korean J Hepatol 2010;16(3):315-320

21. Marcellin P, Heathcote EJ, Buti M, Gane E, de Man RA, Krastev $Z$, Germanidis $G$, et al. Tenofovir disoproxil fumarate versus adefovir dipivoxil for chronic hepatitis B. N Engl J Med 2008;359(23):2442-2455

22. Lee HS, Yoo BC, Lee KS, Kim JH, Um SH, Ryu SH, Lee YS, et al. Clevudine-induced viral response, associated with continued reduction of HBsAg titer, was durable after the withdrawal of therapy. J Gastroenterol 2011;46(3):410-414

23. Kim JH, Yoo BC, Yeon JE, et al. Treatment with clevudine for 24 weeks results in sustained antiviral response associated with continued HBsAg decrease 24 weeks post-treatment in $\mathrm{HBeAg}$ positive patients. J Hepatol, 2009; 50(S1):S383

24. Izzedine H, Hulot JS, Launay-Vacher V, Marcellini P, Hadziyannis SJ, Currie G, Brosgart CL, et al. Renal safety of adefovir dipivoxil in patients with chronic hepatitis B: two double-blind, randomized, placebo-controlled studies. Kidney Int 2004;66(3): 1153-1158 